\title{
A conservation agenda for the Pantanal's biodiversity
}

\author{
Alho, CJR. * and Sabino, J. \\ Programa de Pós-graduação em Meio Ambiente e Desenvolvimento Regional, \\ Universidade Anhanguera - Uniderp, CEP 79037-280, Campo Grande, MS, Brazil \\ *e-mail: alho@unb.br
}

Received October 14, 2010 - Accepted December 13, 2010 - Distributed April 30, 2011

\begin{abstract}
The Pantanal's biodiversity constitutes a valuable natural resource, in economic, cultural, recreational, aesthetic, scientific and educational terms. The vegetation plus the seasonal productivity support a diverse and abundant fauna. Many endangered species occur in the region, and waterfowl are exceptionally abundant during the dry season. Losses of biodiversity and its associated natural habitats within the Pantanal occur as a result of unsustainable land use. Implementation of protected areas is only a part of the conservation strategy needed. We analyse biodiversity threats to the biome under seven major categories: 1) conversion of natural vegetation into pasture and agricultural crops, 2) destruction or degradation of habitat mainly due to wild fire, 3) overexploitation of species mainly by unsustainable fishing, 4) water pollution, 5) river flow modification with implantation of small hydroelectric plants, 6) unsustainable tourism, and 7) introduction of invasive exotic species.
\end{abstract}

Keywords: biodiversity, conservation, environmental threats, fauna, flora.

\section{Uma agenda de conservação para a biodiversidade do Pantanal}

\section{Resumo}

A biodiversidade do Pantanal constitui recurso natural com reconhecido valor na economia, na cultura, na recreação, na estética, na ciência e na educação. A vegetação, mais a produtividade sazonal, suporta uma fauna abundante. Muitas espécies ameaçadas de extinção ocorrem na região e aves aquáticas são excepcionalmente abundantes durante a estação seca. Perdas da biodiversidade do Pantanal e de seus hábitats naturais associados ocorrem como resultado do uso não sustentável da terra. A implementação de áreas protegidas é somente uma parte da estratégia necessária. Analisamos as ameaças ambientais do bioma sob sete tópicos principais: 1) conversão da vegetação natural em pasto e campos agrícolas; 2) destruição e degradação de hábitats, principalmente pelo emprego de fogo; 3) sobre uso de espécies, principalmente pela pesca; 4) poluição de água; 5) modificação de fluxo de rios, principalmente pela implantação de pequenas usinas hidrelétricas; 6) turismo não sustentável; e 7) introdução de espécies invasoras exóticas.

Palavras-chave: biodiversidade, conservação, ameaças ambientais, fauna, flora.

\section{Introduction}

As a wetland, the Pantanal is a biome characterised by constant or recurrent shallow flooding near the surface of the substrate, due to the low drainage capacity of its river system. This is the most remarkable feature of the Pantanal, with a dynamic that alternates annual cycles of droughts and floods, and determines the ecological interactions and patterns of biological diversity (Junk et al., 1989, 2006). The climatic and hydrological processes between plateau and surrounding plains are essential to maintain this water system, a fact that qualifies the Pantanal biome as a complex and unique system. The flood plain comprises approximately $60 \%$ of the geographical extent of the Upper Paraguay River Basin (Harris et al., 2005, 2006). Three major factors characterise the Pantanal wetland: water, substrate and biota (Alho, 2005). Most of the Pantanal fauna is widely distributed and endemic species are rare in the biome (Brown-Junior, 1984; Junk et al., 2006, Lourival et al., 2000).

The Pantanal is also characterised by a high density of various species of large vertebrates, with densities of populations that are not observed in any other biome in Brazil. Inventories carried out by Conservation International-Brazil showed average densities of 4.3 for alligators, 1.8 for capybaras, and 0.3 for marsh deer per square kilometre, population concentrations that provide an enormous potential for ecotourism and wildlife management (Willink et al., 2000). Similarly as for birds and mammals, the region has many species of fish with high populations, especially 
those whose food supply is based on organic material (Britski et al., 2007; Fernandes et al., 2009). Additionally, demographically healthy populations of many endangered species such as the Brazilian giant otter (Pteronura brasiliensis), the jaguar (Panthera onca) and the greater hyacinth macaw (Anodorhynchus hyacinthinus) are still viable in the Pantanal. These characteristics, combined with the high degree of conservation, are responsible for the inclusion of the Pantanal in the National Heritage List in the Brazilian Constitution of 1998 and the inclusion of the biome in the Ramsar Convention on Wetlands of International Importance (Willink et al., 2000; Alho, 2005); it is also considered one of the 37 major wilderness areas remaining on Earth (Mittermeier, 2002).

The region is formed by a complex mosaic of different kinds of habitats, strongly dependent on seasonal flooding. The present landscape arrangement and natural ecosystems are the result of three factors: 1) evolutionary changes occurring since the Quaternary, which probably influenced the drainage patterns of the region; 2) the pronounced differences in annual cycles of wet and dry seasons plus exceptional periods of long flooding or droughts causing retraction or expansion of the Pantanal, thus being a phenomenon related to greater or lesser primary productivity and ecological succession and 3) areas involving human intervention such as pastures, artificial ponds or introduced trees near the ranch houses (Alho, 2005).

As seen throughout this volume on articles describing the flora and fauna, the mixture of major vegetation formations that occur in the Pantanal has resulted in diverse and abundant fauna. The species which are able to exploit a wide range of resources have become both widespread and locally abundant.

The implementation of the Convention on Biological Diversity has continued since its conclusion in 1992 on the occasion of the UN Conference on Environment and Development in Rio de Janeiro. Although there are a number of conservation initiatives, including plans, programmes and projects such as "Priority Areas and Actions for Biodiversity Conservation - Cerrado and Pantanal = Áreas e Ações Prioritárias para Conservação da Biodiversidade - Cerrado e Pantanal" (MMA, 2007), a conservation synthesis on biodiversity status has been recently published worldwide (Millennium Ecosystem Assessment, 2005a-k). The third edition of Global Biodiversity Outlook (GBO-3), produced by the Convention on Biological Diversity (CBD) points out that the world has failed to meet its target of achieving a significant reduction in the rate of biodiversity loss by 2010 (Secretariat of the Convention on Biological Diversity, 2010).

The aim of this paper is to provide a concise review of the Pantanal's biodiversity conservation, discussing the environmental threats and suggesting conservation needs.

\section{Methods}

This article is based on two approaches: 1) literature review and 2) the experience of the authors with the biome, including scientific research combined with labour-management policies for scientific use and conservation of biodiversity in NGOs and government agencies, carried out in different regions within the considerable scale of time.

To list the endangered species in the Pantanal and surroundings, we consulted the IUCN Redlist (IUCN, 2010, $\mathrm{CR}=$ Critical Endangered, $\mathrm{EN}=$ Endangered, $\mathrm{VU}=$ Vulnerable, NT $=$ Near Threatened), and the official Brazilian List of Threatened Fauna (MMA, 2003) and threatened fishes and invertebrates (MMA, 2004).

\section{Results and Discussion}

The major challenge for the Pantanal is to meet the growing demand for social and economic development, mainly cattle ranching, agriculture, urban growth and tourism, while conserving biodiversity and providing essential ecosystem services for water quality, landscape integrity and wildlife protection.

These challenges are aligned with the development of new economic paradigms and environmental issues, which require - in addition to scientific knowledge and new technologies - innovative business models that valorise the natural capital and induce cultural changes. Natural Capital - providing ecosystems and biodiversity benefits for humankind - clearly underlies everything. Yet the annual loss of land-based Natural Capital - in terms of lost human welfare benefits from forest loss alone - has reached US\$ 2 trillion to US\$ 4.5 trillion (TEEB, 2010). Obviously, these innovative concepts are appropriate to the Pantanal and models of environmental evaluation should be customised for the region.

\subsection{Threats}

The major conservation problems of the Pantanal floodplain originate on the plateaus. The surrounding region has an important ecological role for the Pantanal, as it serves as source areas for the animal species and is essential in the maintenance of hydrological processes and the system of drought and floods (Brown-Junior, 1984; Willink et al., 2000). Consequently, preservation of the Pantanal is directly linked to preservation of the adjacent Cerrado. New trends in economic development are shown as the main threats to biodiversity in the Pantanal and its surroundings (Alho, 2008a; Harris et al., 2005, 2006; Junk and Cunha, 2005; Willink et al., 2000). Many farms have been established in the highlands surrounding the Pantanal and much of the natural vegetation (savanna) has been converted to soybean plantations or by other activities (Alho, 2005; CI et al., 2009). Among these problems are erosion, compacted soil, expansion of exotic pasture areas, silting rivers, pollution of water sources including by environmental contaminants (e.g. mercury), alterations in the water level, damming of rivers, and deposits of sewage and solid waste (Harris et al., 2005, 2006).

Deforestation, expanding agriculture, illegal fishing and hunting, unplanned tourism, and pollution by pesticides have 
also caused a progressive deterioration of natural habitats. Because of the huge demand for soybean plantations on the upland plateaus surrounding the Pantanal, the application of toxic agricultural chemicals is very common (Alho, 2005; Harris et al., 2005, 2006).

These environmental threats result in many endangered species, belonging to major taxa of Mammalia, Birds, Reptilia, Actinopterygii, Bivalves and Lepidoptera (Table 1). In the Pantanal, 20 species were from the official Brazilian List of Threatened Fauna (MMA, 2004) and threatened fishes and invertebrates (MMA 2004), and the IUCN listed four species in category "Endangered", eight "Vulnerable" and 17 "Near Threatened", while in the surrounding areas there were 22 species from the Brazilian List, and the IUCN showed one species "Critically Endangered", two "Endangered", seven "Vulnerable", and 18 "Near Threatened" (Table 1).

The environmental threats to the Pantanal's biodiversity can be grouped under seven interacting categories: 1) conversion of natural vegetation into pasture and agricultural crops, 2) destruction or degradation of habitat mainly due to wild fire, 3 ) overexploitation of species mainly by unsustainable fishing, 4) water pollution, 5) river flow modification with implantation of small hydroelectric plants, 6) unsustainable tourism, and 7) introduction of invasive exotic species. More recently, two other factors have proven devastating to populations and ecosystems, adding to the list: pathogen pollution, and global environmental change linked to climate (a direct effect on biodiversity and human health related to climate change is the likely increase in infectious diseases transmitted by insects or through contaminated water).

\subsubsection{Conversion of natural vegetation into pasture and agricultural crops}

A study carried out to present the results of monitoring changes in vegetation and land use in the Brazilian part of the Upper Paraguay River Basin (Bacia do Alto Paraguai) BAP, (with a total area of $368,640 \mathrm{~km}^{2}$ ), considering the period from 2002 to 2008 , showed that the region has been suffering the consequences of the expansion in cattle ranching and agricultural activities, especially in the highland region (CI et al., 2009). This study points out that while the Pantanal maintains $86.6 \%$ of its natural vegetation, the surrounding upland plateaus (planaltos) have kept only $41.8 \%$ of their original vegetation cover. During the short period from 2002 to 2008, the Brazilian side of the BAP lost $4 \%$ of its vegetation on the plateaus and $2.4 \%$ in the floodplain (the Pantanal). Data for 2008 show that cattle ranching is responsible for $11.1 \%$ of vegetation conversion in the Pantanal and $43.5 \%$ in the upland plateaus.

\subsubsection{Destruction or degradation of habitat mainly due to wild fire}

Fire is a major threat. Ranchers in the Pantanal set fire to the vegetation during the dry season as a "management" technique to "clear" the vegetation not used by cattle. The fire is initially started in the grassland but due to open areas, dry vegetation and wind, the fires often spread to savannas, woodland and forest (Alho, 2005). Removal of natural vegetation eliminates food and shelter, especially for forest-dwelling wildlife and epiphytic plants. Deforestation also increases erosion since most elevated areas have sandy soil that is easily blown or washed away by rain.

\subsubsection{Overexploitation of species mainly by unsustainable fishing}

Deforestation also affects fish since migration may be influenced by terrestrial habitat disturbances, mainly gallery forests and seasonally flooded fields. In the "piracema" - a kind of migration - the schools of fish move upstream at the beginning of the rainy season. Other migratory fish species leave the riverbed and move into the adjacent flooding areas searching for food.

Species of large fish such as jaw characins (Salminus brasiliensis), spotted surubim (Pseudoplatystoma corruscans), barred surubim (Pseudoplatystoma fasciatum), streaked prochilod (Prochilodus lineatus), "piraputanga" (Brycon hilarii) and threespot leporinus (Leporinus friderici) are some of the most remarkable Pantanal ichthyofauna (Menezes, 1994). This is due, in part, to the size of these

Table 1. Number of threatened species for the Pantanal and surroundings, based on IUCN Redlist (CR - Critical Endangered, EN - Endangered, VU - Vulnerable, NT - Near Threatened), and official Brazilian List of Threatened Fauna and Threatened Fish and Invertebrates (MMA, 2003, 2004).

\begin{tabular}{|c|c|c|c|c|c|c|c|c|c|c|}
\hline \multirow{2}{*}{ Taxon } & \multicolumn{5}{|c|}{ Pantanal } & \multicolumn{5}{|c|}{ Surroundings } \\
\hline & CR & EN & VU & NT & MMA & CR & EN & VU & NT & MMA \\
\hline Mammals & 0 & 1 & 5 & 10 & 13 & 0 & 1 & 5 & 9 & 13 \\
\hline Birds & 0 & 3 & 3 & 7 & 7 & 1 & 1 & 1 & 9 & 4 \\
\hline Reptiles & 0 & 0 & 0 & 0 & 0 & 0 & 0 & 1 & 0 & 0 \\
\hline Fishes & 0 & 0 & 0 & 0 & 0 & 0 & 0 & 0 & 0 & 2 \\
\hline Bivalves & 0 & 0 & 0 & 0 & 0 & 0 & 0 & 0 & 0 & 2 \\
\hline Lepidoptera & 0 & 0 & 0 & 0 & 0 & 0 & 0 & 0 & 0 & 1 \\
\hline Total & 0 & 4 & 8 & 17 & 20 & 1 & 2 & 7 & 18 & 22 \\
\hline
\end{tabular}


large fish species that are valuable for professional and amateur fishing (Catella, 2004). Less evident and less known, but no less important, are the small fish species, which are up to $15 \mathrm{~cm}$ in length. Without the small characins, small catfish and small armored catfish, many large species could not exist: small species support aquatic food-chains, or are food-chain links, and essentially are fish whose biological richness is yet to be adequately evaluated, especially in the headwaters of the Pantanal (Sabino and Prado, 2006).

There is evidence of overfishing in some large fish species (Garcia, 2006), a major threat hanging over the water system of the Pantanal, which may adversely affect the flood pulse of the plain. About $70 \%$ of the water of the Pantanal wetland originates in the northern part of the basin, and the Cuiaba River, forming the main tributary of the Pantanal, contributes $40 \%$ of the water system (Brasil, 1997). Consequently, the information that $75 \%$ of all 115 dam projects planned for the Upper Paraguay basin (BAP) are in the northern region, in Mato Grosso State (ANEEL, 2010), gives a glimpse of a disturbing scenario since all these developments may change the hydrodynamics and floods in the wetland plain (Girard, 2002). A simple change in the regime of droughts and floods in this biome has already produced worrying results, since the main trigger for the reproduction of fish is the rise in river level with the first rains. Consequently, changes in this pattern negatively affect the reproductive cycle. When the fish run into an insuperable obstacle and a lake, their reproductive cycle is not completed because spawning occurs in the upper river (Godinho et al., 2009).

When dams are installed, conservation of the fish fauna, particularly migratory species, requires that connectivity is restored between the river channel and its flood areas (wetlands). Additionally, they are eco-hydrological studies which would be required in each river to assess the flow rates, in the flood period, timing of the spawning migration period and to ensure the survival of juvenile forms of fish (Calheiros et al., 2009).

\subsubsection{Water pollution}

The introduction of toxins and other contaminants to the Pantanal is an undesirable trend in habitat quality, since it affects valuable wildlife and fish resources as well as the quality of associated natural resources, including surface and ground water. The introduction of pollutants to ecosystems results in changes in an interrelated series of variables or processes that can affect the structure and function of the ecosystem in the short or long term.

Alho and Vieira (1997) point out that unregulated gold mining has contaminated Pantanal habitats with mercury. Fish samples showed high percentages of contamination (Cuiaba and Bento Gomes rivers) with mercury beyond the levels allowed by international standards for contamination. Bird species, which feed on fish, like the olivaceous cormorant Phalacrocorax olivaceu, the limpkin Aramus guarauna and the snail-kite Rosthramus sociabilis were also contaminated.

\subsubsection{River flow modification with implantation of small hydroelectric plants on the upland plateaus}

The floodplain is mainly formed by the tributaries from the left margin of the Paraguay River, in Brazil, with its western border following that of Brazil itself, touching Bolivia to the north and Paraguay to the south. The streams and rivers on these highlands are most prevalent where rainfall is ample, during the wet season. On the plateaus small brooks flow into small rivers, which flow into larger ones. The large rivers are shaped mainly by terrain, velocity of the water, levels of dissolved oxygen, nutrient loads, temperature and type of riverbed. The major rivers feeding the Pantanal are (from north to south): Paraguay, Bento Gomes, Cuiaba, São Lourenço-Itiquira, Taquari, Negro, Aquidauana-Miranda, Nabileque and Apa. These rivers are slow-moving when they meet the flatland and have coves with adjacent flood-land. They periodically overflow their banks. The maze of fluctuating water levels, nutrients, and wildlife forms a dynamic ecosystem. Flood-lands cover about $80 \%$ of the whole Pantanal. In contrast, during the dry season, most of the flooded areas stay dry, when the water returns to the river-beds (Alho, 2005, 2008a).

In particular, these changes may threaten water conservation in the main protected area and Ramsar Site, the Pantanal National Park. It is noteworthy that three quarters of these enterprises involve small hydro power-plants ( $\mathrm{PCH}$, from Portuguese acronym), located or planned for the same river, together resulting in an important impact. Even small power-plants, which may not form a reservoir, can change the discharge of nutrients and suspended matter and hence the cycling of nutrients in affected water bodies (Calheiros et al., 2009; Fernandes, 2010). Furthermore, the presence of the physical barrier in the form of a dam is known to prevent the movement of migratory fish species during the spawning season, affecting fish production in the medium and long term (Fernandes et al., 2009; Suzuki et al., 2009). All these changes and negative impacts on the water ecology of each sub-basin forming the Pantanal should be assessed simultaneously, in terms of the integrated area of the Upper Paraguay River Basin, prior to installing such projects (Calheiros et al., 2009).

\subsubsection{Unsustainable tourism}

Tourism, if well planned and regulated, provides an excellent alternative economy for the region. There is a booming tourist trade in the Pantanal. Unfortunately, most of this tourism is predatory. Tour groups may invade areas that should be preserved (e.g., waterfowl nesting grounds or rookeries), sport fishing groups may over-fish, in general spreading litter, particularly in illegal camp sites in gallery forest, where these fishermen leave signs of their predatory presence. Numerous tourist hotel boats throughout the Pantanal do not treat waste properly and spread solid waste on their way (Alho, 2005). 


\subsubsection{Introduction of invasive exotic species}

Exotic species introduction has been one of the most important factors of biodiversity loss in the region, as discussed in a specific chapter of this volume.

\subsection{Conservation agenda}

Important comprehensive global analyses on biodiversity conservation and sustainable use have been produced and published: on the ecosystem and human well-being (Millennium Ecosystem Assessment, 2005a-k); on the importance of biodiversity in human health (Chivian and Bernstein, 2008); on the implementation of the objectives of the Convention on Biological Diversity (Secretariat of the Convention on Biological Diversity, 2010).

Biodiversity plays a fundamental role as ecosystem services in the maintenance of natural ecological processes. The economic or utilitarian values of biodiversity rely upon the dependence of man on biodiversity, involving the products that nature can provide: fishing resources, tourism and extractive products. It also encompasses ecosystem services, such as climate regulation, reproductive and feeding habitats for commercial fish, some organisms that can create soil fertility through complex cycles and interactions, such as earthworms, termites and bacteria, in addition to the fungi responsible for cycling nutrients like nitrogen, phosphorus and sulfur and making them available for plant absorption. These services are the benefits that people indirectly receive from natural ecosystem functions (air quality maintenance, regional climate, water quality, nutrient cycling, reproductive habitats of commercial fish, etc.) with their related economic values (Alho, 2008b).

The following conceptual levels of ecosystem are important in the Pantanal:

- Species diversity - the number of species found in a given study area or in a kind of habitat. Although the species diversity of the Pantanal is not high in comparison to other Brazilian biomes, the abundance of species, including endangered species, is high.

- Functional diversity - the web of functions that are performed by species in a system, for example, the role of gallery forest for arboreal mammals, and the rhythms of seasonal production of food (shoots, flowers and fruits) for arboreal primates. Also includes feeding guilds of waterfowl observed in the Pantanal.

- Genetic diversity - genetic variability within a species, that is, variation among individuals or populations.

- Community and ecosystem diversity - assemblages of interacting different species also interacting with abiotic components of the environment, such as the cordilheira habitat of the Pantanal.

- Habitat diversity - characteristics of a given area where species, population and communities occur. The Pantanal has a great variety of different kinds of habitats. Alteration and loss of natural habitat is one of the most severe negative impacts on biodiversity.

Traditionally, the conservation agenda employs the implementation of conservation units in selected priority areas, with relevant biological attributes. This has been shown to be insufficient. The agenda needs to include other approaches, such as economic incentives that would induce stakeholders to adopt initiatives that balance economic interest and nature protection. In the Pantanal there is enormous potential for ecotourism or well-planned tourism in the wild.

Wildlife watching, particularly ecotourism, is a form of tourism based on the principles of making an active contribution to the conservation of the natural and cultural legacy and interpreting the region's natural and cultural heritage for visitors. Ecotourism is often based on relatively low levels of tourism in an area, and is therefore particularly suited to organised tours for small groups, and also for independent travelers. In the Pantanal planning for this kind of operation must increase to help local communities generate sustainable income and employment. To be sustainable, tourism needs to make a positive contribution to the natural and cultural environment, generate benefits for the host communities, not put at risk the future livelihood of local people, and to make every effort to anticipate and prevent economic, environmental, social and cultural degradation (Tapper, 2006).

Wildlife watching tourism in the Pantanal needs to integrate considerations of sustainable development into the way in which it is operated and managed, and combine efforts for environmental education, including the construction of facilities for visitors, such as a public aquarium, thus improving the structure of environmental interpretation. Wildlife watching tourism also involves appropriately operated tourism activities that include local communities, wildlife managers in public and private sectors, national and local government, conservation NGOs (particularly wildlife societies which have a role in popularizing and raising awareness about wildlife and conservation). The tourism sector includes tour operators, local operators, excursion providers, accommodation and, of course, the tourists themselves (Cochrane, 2003; Tapper, 2006).

A wide range of recommendations should also be offered to managers of the environmental and water resources of the two states in which the Pantanal is located (Mato Grosso and Mato Grosso do Sul), and managers of Brazilian electric sector. The decision makers need to be made aware of the fragility of the biome and the effect of changes in hydrological cycles arising from construction of small dams for hydroelectricity. Among the suggestions, particularly urgent is an Integrated Environmental Assessment on the impacts of the use of electric power from the Alto Paraguay (Calheiros et al., 2009). Reports focused on basins north of the BAP show that the migration of fish was negatively affected at several points, compromising their reproduction and distribution in the Pantanal. When faced with unsatisfactory conditions for their survival, some fish species tend to decrease in 
number or size and even disappear, especially migratory species (Calheiros et al., 2009). Based on the available scientific information on the basin of the Upper Paraguay and Pantanal, specific guidelines for the sustainability of the region must be formulated (e.g., Conservation Plan of the Upper Paraguay Basin - PCBAP, Fund for Global Environment and Global Environment Facility - GEF Alto Paraguay, among others) for the conservation of ecological processes that govern the functioning of this biome. One way to ensure the ecological processes of fish fauna is to keep some sub-basins of the BAP free from any dams (Calheiros et al., 2009).

However, conservation involves combining both natural ecosystems and human societies, and conservationists deal with systems that are extremely complex and fragile, as is the case of the Pantanal. Sometimes, the urgent nature of the problem demands that the stakeholder take immediate action in their own interests, despite the risks inherent in the lack of certainty about how best to proceed.

Protected areas are a basis of conservation policies and provide multiple benefits. There are over 120,000 designated protected areas covering around $13.9 \%$ of the Earth's land surface. Despite its importance, just $0.55 \%$ of an area of $140,000 \mathrm{~km}^{2}$ - only in Brazil - of the Pantanal is protected by federal conservation units (Harris et al., 2006).

On a global scale, there has been a positive assessment of the implementation of public policies on science and technology for the use and conservation of biodiversity (Millennium Ecosystem Assessment, 2003, 2005a-k). The success of these actions was made possible by unprecedented international cooperation among taxonomists from a wide range of research institutions and collections, including museums and herbaria, universities, botanical gardens and collections of biological resources (Higushi, 2006). This is still a drop in the ocean, considering the challenges facing the Pantanal and surroundings. Fortunately, recent investments, which include the creation of research programmes (e.g., Rede Centro-Oeste and SisBiota, from the Ministry of Science and Technology, and Biota-MS Programme, from Mato Grosso do Sul State) and institutions (e.g., National Institute of Wetlands, the INAU) look set to reverse this situation in Brazil. In the medium and long term, to expand and strengthen these coordinated scientific networks, it is necessary to build and maintain long-term biodiversity research programmes in the Pantanal, based on liaison between regional and national entities that work with biodiversity.

Priority topics and guidelines for conservation:

\section{Environmental issues}

\section{Land use, soil conservation and management}

1) Promote agricultural practices for soil use that avoid loss of soil, including erosion.

2) Promote economic activities related to the objectives of the protected areas' buffer zones and experimental projects for extractive reserves.

\section{Water resources}

1) Develop mandatory requirements for integrated studies on environmental impact of large development projects, such as waterways.

2) Secure the control of environmental contaminants, including pesticides, according to international protocols.

3) Enforce the existing legislation on water resources, including their springs.

4) Consider the hydrological basin and micro basin as a conservation unit or ecosystem.

5) Implement the effective participation of the Basin Committees in order to enforce legislation.

6) Promote the conservation of wetlands that within the framework of the Ramsar Convention.

\section{Air pollution and climatic change}

1) Establish shared management between Government agencies and civil society to control wildfire.

2) Conduct technical training, environmental education, and campaigns to prevent and combat wildfire.

3) Carry out environmental restoration in degraded areas for carbon absorption (carbon capture), among other benefits.

\section{Biodiversity: conservation, research and sustainable use}

1) Promote the expansion of protected areas, ideally to reach $10 \%$ of the region as intended by the Government (40\% of indirect use conservation units and $60 \%$ of direct use).

2) Secure land ownership in protected areas, the development of their management plan and its effective implementation, including the necessary staff.

3) Target priority incentives for the creation of private reserves (RPPN).

4) Promote incentives for the implementation of ecological sales taxes (ICMS Ecológico).

5) Undertake the administration of bioregional areas including the concept of ecoregions and biosphere reserves.

6) Carry out experimental pilot projects for sustainable use in protected areas of direct use.

7) Provide incentives for the creation of ex-situ reserves.

8) Provide incentives for sustainable use of biological resources including wildlife.

9) Promote the certification of products from sustainable use programmes.

\section{Scientific and technological issues}

\section{Research and technology}

1) Support shared participation between Government and the private sector, aiming at the achievement of innovative technologies. 
2) Promote basic and applied research for the sustainable use of resources and technological practices for sustainable development.

\section{Institutional issues}

\section{Institutional strength and shared management}

1) Integrate information and actions of institutions engaged in conservation of the region.

2) Promote government policies to implement organisational strength including infrastructure, personnel, programmes and dissemination of results.

\section{Legal and economic instruments}

1) Integrate sectoral policies in order to promote regional conservation and development.

2) Create incentives for shared environmental management at all levels.

3) Promote law enforcement.

4) Implement ecological-economic zoning.

\section{Social-cultural issues}

\section{Land use, territorial expansion with new agricul-} tural frontiers

Produce guidelines for implementing ecologicaleconomic zoning through shared participation and development indicators for sustainability.

\section{Urban and metropolitan expansions}

Develop means to control urban migration.

\section{Poverty and life quality}

Develop programmes to support health and education for better quality of life.

\section{Cultural diversity and traditions}

Recognise the value of ethno-cultural diversity and traditional knowledge for conservation and sustainable use of resources.

\section{Communication and environmental education.}

Plan, regulate and implement programmes on environmental education to spread and consolidate the education process of local people and to disseminate information through modern means of communication.

\section{Economic issues}

\section{Mineral exploitation}

1) Conduct sustainable mining.

2) Create environmental certification for mining.

3) Integrate the process of authorisation, law enforcement, and control of mining.

\section{Eco-business and sustainable tourism}

1) Develop incentives for sustainable use of biodiversity.

2) Develop incentives for sustainable tourism.
3) Create tourist facilities, such as public aquariums and zoos, to disseminate biodiversity information by means of environmental education programmes.

\section{Infrastructure}

1) Harmonise planning and implementation of infrastructure, mainly for transport and energy, with recommendations for ecological-economic zoning, as well as undertaking reliable studies on environmental impact for each case.

\section{References}

Agência Nacional de Energia Elétrica - ANEEL, 2010. Quadro de acompanhamento de autorizações das PCH's.I Ministério de Minas e Energia. Available from: http://www.aneel.gov.br/ aplicacoes/autorizacoes/default_aplicacao_acompanhamento. cfm?IDACOMPANHAMENTOTIPO=4. Access in: 25 jun. 2010.

ALHO, CJR., 2005. The Pantanal. In: FRASER, LH. and KEDDY, PA., Org. The world's largest wetlands - Ecology and conservation. New York, USA: Cambridge University Press. p. 203-271.

-, 2008a. Biodiversity of the Pantanal: response to seasonal flooding regime and to environmental degradation. Brazilian Journal of Biology, vol. 68, no. 4, p. 957-966. Suppl.

-, 2008b. The Value of Biodiversity. Brazilian Journal of Biology, vol. 68 , no. 4, p. 1115-1118. Suppl

ALHO, CJR. and VIEIRA, LM., 1997. Fish and wildlife resources in the Pantanal wetlands of Brazil and potential disturbances from the release of environmental contaminants. Environmental Toxicology and Chemistry, vol. 16, no. 1, p. 71-74.

BRASIL, 1997. Ministério do Meio Ambiente, dos Recursos Hídricos e da Amazônia Legal. Secretaria de Coordenação dos Assuntos de Meio Ambiente. Programa Nacional do Meio Ambiente. Plano de conservação da Bacia do Alto Paraguai (Pantanal): PCBAP. Análise integrada e prognóstico da bacia do Alto Paraguai. Brasília, DF: PNMA. 12 v.

BRITSKI, HA., SILIMON, KZS. and LOPES, BS., 2007. Peixes do Pantanal - Manual de identificação. 2. ed. Corumbá: EMBRAPA. p. 227.

BROWN-JUNIOR, K., 1984. Zoogeografia da região do Pantanal Mato-grossense. In: Anais do Simpósio sobre os Recursos Naturais e Sócio-Econômicos do Pantanal. Brasília, DF: EMBRAPA. p. 137-78.

CALHEIROS, D., ARNDT, E., RODRIGUEZ, EA. and SILVA, MCA., 2009. Influências de usinas hidrelétricas no funcionamento hidro-ecológico do Pantanal Mato-Grossense Recomendações. EMBRAPA. Documento, no. 102. Available from: http://www.cpap.embrapa.br/publicacoes/online/DOC102.pdf. Access in: 20 jun. 2010.

CATELLA, AC., 2004. A pesca no Pantanal Sul: situação atual e perspectivas. Corumbá: EMBRAPA Pantanal. Documentos, no. 48.

CHIVIAN, E. and BERNSTEIN, A., Eds., 2008. How human health depends on biodiversity., New York: Oxford University Press. 566 p.

COCHRANE, J., 2003. Forging links between protected areas and the tourism sector: how tourism can benefit conservation. Paris: UNEP. p. 13-14. Available from: www.uneptie.org/tourism. 
Conservação Internacional - CI, Ecologia e Ação - ECOA, Fundación AVINA, Instituto SOS Pantanal and WWF- Brasil, 2009. Monitoramento das alterações da cobertura vegetal e uso do solo na Bacia do Alto Paraguai Porção Brasileira. Available from: http://assets.wwfbr.panda.org/downloads/ mapacoberturabaciaaltoparaguai_estudocompleto.pdf. Access in: 20 jul. 2010.

FERNANDES, IM., MACHADO, FA. and PENHA, J., 2010. Spatial pattern of a fish assemblage in a seasonal tropical wetland: effects of habitat, herbaceous plant biomass, water depth, and distance from species sources. Neotropical Ichthyology, vol. 8, no. 2 , p. 289-298.

FERNANDES, R., AGOSTINHO, AA., FERREIRA, EA., PAVANELLI, CS., SUZUKI, HI., LIMA, DP. and GOMES, LC., 2009. Effects of the hydrological regime on the ichthyofauna of riverine environments of the Upper Paraná River Floodplain. Brazilian Journal of Biology, vol. 69, no. 2, p. 669-680. Suppl.

GARCIA, ICB., 2006, Influência da pesca seletiva sobre o comprimento médio de maturação em população de Dourado (Salminus brasiliensis), Piraputanga (Brycon hilarii) e Curimbatá (Prohilodus lineatus) no Rio Miranda. Campo Grande: Universidade Federal de Mato Grosso do Sul - UFMS. 46 p. Dissertação de mestrado em ecologia e conservação.

GIRARD, P., 2002. Efeito cumulativo das barragens no pantanal: mobilização para conservação das áreas úmidas do Pantanal e Bacia do Araguaia. Campo Grande, MS: Instituto Centro Vida. 28 p. Relatório. Available from: http://www.riosvivos.org.br/ dowloads/Efeito_cumulativo_barragens_Pantanal.pdf. Access in: 22 jun. 2010

GODINHO, AL., LAMAS, IR. and GODINHO, HP., 2009. Reproductive ecology of Brazilian freshwater fishes. Environmental Biology of Fishes, vol. 87, p. 143-162.

HARRIS, MB., TOMAS, WM., MOURÃO, GM., DA SILVA, CJ., GUIMARÃES, E., SONODA, F. and FACHIM, E., 2005. Desafios para proteger o Pantanal brasileiro: ameaças e iniciativas em conservação. Megadiversidade, vol. 1, no. 1, p. 156-164

HARRIS, MC., ARCÂNGELO, C., PINTO, ECT., CAMARGO, G., RAMOS-NETO, MB. and SILVA, SM., 2006. Estimativa da perda de cobertura vegetal original na Bacia do Alto Paraguai e Pantanal brasileiro: ameaças e perspectivas. Natureza e Conservação, vol. 4 , no. 2 , p. $50-66$

HIGUSHI, H., 2006. Biodiversidade: a megaciência em foco. Academia Brasileira de Ciência and Sociedade Brasileira para o Progresso da Ciência. Curitiba, 2006. p. 15. Documento de reunião paralela à COP-08. IUBS - $29^{\text {th }}$ General Assembly/Report of Activities/Annex 3.

IUCN, 2010. IUCN Red List of Threatened Species. Version 2009.1. Available from: www.iucnredlist.org.

JUNK, WJ.; BAYLEY, PB. and SPARKS, RS., 1989. The flood pulse concept in river - floodplain systems. In: DODGE, DP., Ed. Proceedings of the International Larger River Symposium - LARS. Canadian Journal of Fisheries and Aquatic Sciences, vol. 106, p. 110-127.

JUNK, WJ. and CUNHA, CN., 2005. Pantanal: a large South American wetland at a crossroads. Ecological Engineering, vol. 24, p. 391-401.

JUNK, WJ., CUNHA, CN., WANTZEN, KM., PETERMANN, P., STRÜSSMANN, C., MARQUES, MI. and ADIS, J., 2006.
Biodiversity and its conservation in the Pantanal of Mato Grosso, Brazil. Aqua Science, vol. 69, no. 3, p. 278-309.

LOURIVAL, R., HARRIS, MB. and MONTAMBAULT, JR., 2000. Introduction to the Pantanal, Mato Grosso do Sul, Brasil. In WILLINK, PW., CHERNOFF. B., ALONSO. LE., MONTANBAULT, JR. and LOURIVAL EDS, R. A biological assessment of the aquatic eco-systems of the Pantanal, Mato Grosso do Sul, Brazil. Washington, D.C.: Conservation International, p. $28-33$ p.

MENEZES, NA., 1994, Importância da ictiofauna dos ecossistemas aquáticos brasileiros. In: Cadernos dos Seminários Sobre Fauna Aquática e o Setor Elétrico Brasileiro: reuniões temáticas preparatórias - COMASE. Rio de Janeiro: Eletrobrás. p. 7-13.

Millennium Ecosystem Assessment, 2003. Ecosystems and human well-being: a framework for assessment. Washington, D.C.: Island Press. The millennium ecosystem assessment series.

-, 2005a. Ecosystems and human well-being: current state and trends. vol. 1. Washington, D.C.: Island Press. The millennium ecosystem assessment series.

-, 2005b. Ecosystems and human well-being: scenarios. vol. 2. Washington, D.C.: Island Press. The millennium ecosystem assessment series.

-, 2005c. Ecosystems and human well-being: policy responses. vol. 3. Washington, D.C.: Island Press. The millennium ecosystem assessment series.

-, 2005d. Ecosystems and human well-being: multiscale assessments. vol. 4. Washington, D.C.: Island Press. The millennium ecosystem assessment series.

-, 2005e. Ecosystems and human well-being: our human planet: summary for decision-makers. vol. 5. Washington, D.C.: Island Press. The millennium ecosystem assessment series.

-, 2005f. Ecosystems and human well-being: general synthesis. Washington, D.C.: Island Press. The millennium ecosystem assessment series.

-, 2005g. Ecosystems and human well-being: biodiversity synthesis. Washington, D.C.: Island Press. The millennium ecosystem assessment series.

-, 2005h. Ecosystems and human well-being: disertification synthesis. Washington, D.C.: Island Press. The millennium ecosystem assessment series.

-, 2005i. Ecosystems and human well-being: opportunities and challenges for business and industry. Washington, D.C.: Island Press. The millennium ecosystem assessment series.

-, 2005j. Ecosystems and human well-being: wetland and water synthesis. Washington, D.C.: Island Press. The millennium ecosystem assessment series.

-, 2005k. Ecosystems and human well-being: health synthesis. Washington, D.C.: Island Press. The millennium ecosystem assessment series.

Ministério do Meio Ambiente-MMA, 2003. Lista das espécies da fauna brasileira ameaçadas de extinção. Instrução Normativa, no. 3 .

-, 2004. Espécies ameaçadas de extinção e espécies sobreexplotadas ou ameaçadas de sobreexplotação, os invertebrados aquáticos e peixes. Instrução Normativa, no. 5. 
-, 2007. Biodiversidade do cerrado e pantanal: áreas e ações prioritárias para conservação da biodiversidade. Brasília: MMA/SBF. 540 p. Série Biodiversidade, no. 17.

MITTERMEIER, RA., MITTERMEIER, CG., GIL, PA. and PILGRIM, J., 2002. Wilderness: Earth's last wild places. Mexico: CEMEX. 573 p.

SABINO, J. and PRADO, PI., 2006. Vertebrados: síntese do conhecimento da diversidade biológica do Brasil. In: THOMAS, M. and LEWINSO, HN., Org. Avaliação do estado do conhecimento da diversidade brasileira. Brasília: Ministério do Meio Ambiente. vol. 2, p. 55-143.

Secretariat of the Convention on Biological Diversity, 2010. Global biodiversity outlook 3. Montreal. p. 94.

SUZUKI, HI., AGOSTINHO, AA., BAILLY, D., GIMENES, MF., JÚLIO-JUNIOR, HF. and GOMES, LC., 2009. Inter-annual variations in the abundance of young-of-the year of migratory fishes in the Upper Paraná River floodplain: relations with hydrograpfic attributes. Brazilian Journal of Biology, vol. 69, no. 2, p. 649-660. Suppl.

TAPPER, R., 2006. Wildlife watching and tourism: a study on the benefits and risks of a fast growing tourism activity and its impacts on species. Germany: UNEP/CMS Secretariat, Bonn. 68 p.

The Economics of Ecosystems and Biodiversity - TEEB, 2010. Report for business, executive summary 2010. United Nations Environment Programme. p. 20.

WILLINK, PW., CHERNOFF, B., ALONSO, LE., MONTANBAULT, JR. and LOURIVAL, R., 2000. A biological assessment of the aquatic eco-systems of the Pantanal, Mato Grosso do Sul, Brazil, RAP. Bulletin of Biological Assessment, vol. 18 , p. 305 . 